\title{
PROCJENA ZDRAVSTVENOG STANJA STARIJEG STANOVNIŠTVA NA OTOKU CRESU
}

\author{
Lovorka Bilajac ${ }^{1}$, Marina Kučić2 ${ }^{2}$ Zlatko Trobonjača ${ }^{3}$ \\ ${ }^{1}$ Katedra za socijalnu medicinu i epidemiologiju, Sveučilište u Rijeci, Medicinski fakultet, Rijeka, \\ Hrvatska, ${ }^{2}$ Vita, studio za unapređenje zdravlja, Mali Lošinj, Hrvatska, ${ }^{3}$ Zavod za fiziologiju \\ i imunologiju, Sveučilište u Rijeci, Medicinski fakultet, Rijeka, Hrvatska
}

\author{
Autor za korespondenciju: \\ Zlatko Trobonjača \\ zlatko.trobonjaca@uniri.hr
}

primljen: 2019, prihvaćen: 2020, objavljen: 2020.

\section{Apstrakt}

Uvod. Starenje stanovništva predstavlja izazov u ekonomskom, gospodarskom, zdravstvenom i društvenom smislu. Zdravstvena procjena potreba starije populacije provodi se na razini većih sredina, međutim, populacija na otocima pretežno je stara i neprekidno stari. Na Cresu živi 19,9\% starijeg stanovništva, te je cilj ovog istraživačkog rada procjena zdravstvenog stanja starije populacije grada Cresa. Materijali i metode. Za procjenu zdravstvenog stanja korišten je anketni upitnik Short form health survey-36 (SF-36). Mjere zdravstvenog stanja uključuju sastavnice kao što su fizičko, psihičko i društveno funkcioniranje, vitalnost i energija, razna ograničenja zbog fizičkih ili psihičkih poteškoća, tjelesni bolovi te percepcija o općem zdravlju pojedinca. Ispitanici su osobe starije životne dobi koji žive na otoku Cresu. Rezultati. U istraživanju je sudjelovalo 100 stanovnika grada Cresa (43 muškarca i 57 žena), od 65 i više godina. Dobiveni rezultati prema bodovanju svake pojedine čestice ukazuju na to da je društveno funkcioniranje najbolje ocijenjeno $(79,83)$, zatim slijedi ograničenje zdravlja zbog emocionalnih poteškoća $(79,33)$, psihičko ili mentalno zdravlje $(68,08)$, fizičko funkcioniranje $(65,4)$, ograničenje zdravlja zbog fizičkih poteškoća $(60,75)$, vitalnost i energija $(59,86)$ te opće zdravlje $(54,35)$. Zaključak. Procjena zdravstvenog stanja starijeg stanovništva otoka Cresa bolja je u usporedbi s hrvatskom populacijom, a time i kvaliteta života. Muškarci imaju bolju kvalitetu života nego žene te svoje zdravlje percipiraju boljim nego žene. Važnost procjene zdravlja stanovnika očituje se u dobivanju kratkoročnih i dugoročnih podataka o promjenama u zdravlju populacije, čime se kreiraju intervencije s ciljem unapređenja zdravlja osoba starije životne dobi koje žive u manjim sredinama.

Ključne riječi: osobe starije životne dobi, procjena zdravlja, SF-36. 


\section{Uvod}

Starenje stanovništva predstavlja izazov 21. stoljeća u ekonomskom, gospodarskom, zdravstvenom i društvenom smislu. Postoje razlike u očekivanom trajanju života među zemljama pa tako i u udjelu osoba starije životne dobi. Republika Hrvatska sa svojim "vrlo starim stanovništvom” spada u prvih deset država svijeta zbog udjela šezdesetpetogodišnjaka u ukupnom stanovništvu od $17,7 \%$ (1). Trendovi unutar države također se razlikuju, pa tako na otocima živi pretežno staro stanovništvo. Prema popisu iz 2011. na otoku Cresu živi 19,9\% osoba starijih od 65 godina $(1,2)$. Starenje je proces koji se odvija različitom brzinom i u različitoj životnoj dobi, a tri obilježja starenja vrlo su usko povezana. Biološko obilježje objašnjava uzroke i proces starenja na razini stanica i organizma kao cjeline, društveno obilježje starenja objašnjava promjene u odnosu pojedinca i društva, promjene socijalnih aktivnosti, socijalnih interakcija i društvenih uloga starijih osoba, a temeljna pitanja psihološkog obilježja starenja jesu pitanja o organizaciji ponašanja te pitanja o okolnostima u kojima dolazi do dezorganizacije ponašanja tijekom vremena (3). Postoje starije osobe koje odrastaju s dobrom kvalitetom života i zdravljem, s malo patoloških stanja, zadovoljavajućom brigom o sebi, dobrom kontrolom stresa i zadovoljstvom životom. Nasuprot tome, postoje i druge osobe koje su tjelesno neaktivne, kronično umorne, uz dijagnozu sarkopenije, anoreksije, depresivnih simptoma i popratnih komorbiditeta (4). Sva ta stanja utječu na kvalitetu života u starosti, pa procjena kvalitete života obuhvaća široko područje tjelesnih i duševnih stanja, a ne samo jedan od problema (5). Osobe starije životne dobi nisu homogena skupina i ne doživljavaju sebe kao odvojenu populacijsku skupinu, nego predstavljaju integralni dio zajednice u kojoj aktivnim uključivanjem u društvu žive i stvaraju. U kvalitetu života ubrajamo opće zadovoljstvo životom, materijalne životne uvjete, stambene uvjete, raspolaganje vremenom, obrazovanje, zdravlje, društvene odnose, sigurnost, upravljanje i okoliš u kojem pojedinac živi (6).

U svijetu, ali i u Hrvatskoj, za subjektivnu procjenu zdravlja najčešće se koristi generički upitnik Short form health survey-36, SF-36. Jasnoća upitnika, kratkoća i sveobuhvatnost pridonijela je sve većoj upotrebi u ispitivanju zdravstvenog statusa starije populacije (7). Cilj ovog rada je pomoću validirane metode procijeniti i prikazati zdravstveno stanje starije populacije koja živi na otoku Cresu, kao zasebnoj jedinici u odnosu na stanovništvo RH. 


\section{Materijali i metode}

Ispitanici u istraživanju su osobe starije životne dobi (65+), koji nisu dementni i žive cijele godine na otoku Cresu.

Kao instrument istraživanja upotrijebljen je standardizirani anketni upitnik zdravstvenog stanja Short form health survey-36 (SF-36) (5). Sadrži 36 pitanja (čestica). Rezultat se standardno izražava na devet sastavnica koje čine profil zdravstvenog statusa. Fizičko funkcioniranje (engl. physical functioning) sastoji se od deset čestica, ograničenja zbog fizičkih poteškoća (engl. role limitation due to physical problems) sadrži četiri čestice, ograničenja zbog emocionalnih poteškoća (engl. role limitation due to emotional problems) tri čestice, društveno funkcioniranje (engl. social functioning) sadrži dvije čestice, psihičko zdravlje (engl. mental health) pet čestica, vitalnost i energija (engl. vitality/energy) četiri čestice, tjelesni bolovi (engl. bodily pain) dvije čestice, percepcija općeg zdravlja (engl. general health perception) pet čestica i posljednja, deveta sastavnica, promjena u zdravlju (engl. change in helath), sadrži jednu česticu koja se odnosi na promjenu u zdravlju u odnosu na prošlu godinu (5).

Pojedini odgovori na svaku česticu u SF-36 različito se boduju, diferencijalno ponderiraju, prema unaprijed utvrđenim empirijskim normama. Pojedine skale ili sastavnice zdravlja obuhvaćene su različitim brojem čestica, a njihov je broj također empirijski utvrđen u skladu sa psihometrijskim kriterijima pouzdanosti i valjanosti. Svaki se dobiveni odgovor preslikava u numeričke vrijednosti čiji je minimum brojka 0, a maksimum 100. Na taj je način moguće kvantitativno uspoređivati različite sastavnice zdravlja koje upitnik mjeri, prikazati ukupnu razinu i razlikovati osam koncepta zdravlja. Najveći mogući zbroj bodova u upitniku ukazuje na odsutnost nekog negativnog stanja u zdravlju pojedinca, odnosno na dobro zdravstveno stanje. Upitnik je sastavljen tako da se većina pitanja odnose na procjenu zdravstvenog stanja unatrag posljednja četiri tjedna. Na taj su način autori samog upitnika nastojali da odgovori ispitanika budu što manje pod utjecajem trenutnog raspoloženja ili akutnih poteškoća, što bi umanjilo valjanost podataka općenito. Za potrebe ovog istraživanja, uz originalni upitnik SF-36, dodano je pet pitanja demografskog obilježja.

Svaki ispitanik prije samog istraživanja potpisao je Informirani pristanak s jasno naznačenim informacijama o istraživanju. U pisanom obliku objasnio se cilj i svrha istraživanja te se navelo da će se podaci dobiveni iz istraživanja 
koristiti isključivo za znanstvene svrhe. Poštivala su se pravila Helsinške deklaracije te Konvencija o ljudskim pravima i biomedicini Vijeća Europe.

\section{Rezultati}

\section{Demografska slika ispitanika}

U istraživanju je sudjelovalo 100 ispitanika (43\% muškaraca i 57\% žena). Veća zastupljenost žena prati opću demografsku strukturu RH. Ispitanici su osobe starosne dobi od 65 do 93 godine, s prosječnom dobi od 75,91 godina. S obzirom na starosnu dob, $39 \%$ ispitanika spada u ranu stariju dobnu skupinu (65-74 godine), 52\% u srednju stariju dobnu skupinu (75-84 godine), dok je $9 \%$ ispitanika u dubokoj starosti (više od 85 godina). Najveći udio ispitanika živi u vlastitoj kući (53\%), 32\% ispitanika živi u vlastitom stanu. Prema sastavu kućanstva, 19\% ispitanika živi sam/a, 27\% ispitanika živi s partnerom bez djece, $23 \%$ ispitanika živi s partnerom i djecom, dok 16\% ispitanika živi bez partnera s djecom. Njih 15\% dijeli kućanstvo s drugima. Prema stupnju obrazovanja osoba starije životne dobi grada Cresa, njih 46\% ima završenu osnovnu školu, dok je 44\% završilo srednju strukovnu školu. Jedna osoba je završila četiri godine srednje škole, četiri su osobe završile višu školu (VŠS) te pet osoba ima završen fakultet (VSS).

Procjena fizičkog funkcioniranja starije populacije grada Cresa dobivena je pomoću 10 čestica. Rezultati na tri postavljena pitanja fizičkog funkcioniranja ukazuju na postojeća ograničenja. Na pitanje: "Da li Vas trenutno Vaše zdravlje ograničava u podizanju ili nošenju torbe s namirnicama?” 14\% ispitanika je odgovorilo da ih puno ograničava (5M/9Ž), 30\% ispitanika je odgovorilo da malo ograničava nošenje torbe (11M/19Ž), dok je 56\% izjavilo da ih nimalo ne ograničava zdravlje prilikom nošenja torbi s namirnicama (27M/29Ž).

Na pitanje: "Da li Vas trenutno Vaše zdravlje ograničava u hodanju više od jednog kilometara?" 29\% ispitanika odgovorilo je da je puno ograničeno u hodanju više od jednog kilometara (9M/20Ž), 24\% ispitanika je izreklo da postoji malo ograničenja u hodanju više od jednog kilometara (9M/15Ž), a $47 \%$ ih je izjavilo da ih zdravlje nimalo nije ograničavalo pri hodu više od jednog kilometara (25M/22Ž).

Što se tiče ograničavanja zdravlja pri u kupanju ili oblačenju, $88 \%$ ispitanika zdravlje ne ograničava prilikom kupanja ili oblačenja (41M/47Ž).

Na pitanje: "Jeste li u protekla četiri tjedna u svom radu ili drugim redovitim dnevnim aktivnostima obavili manje nego što ste željeli?" dalo je 
pozitivan odgovor $41 \%(16 \mathrm{M} / 25 Z \check{Z})$, a $59 \%$ ispitanika je izreklo da sve obavilo što je htjelo (27M/32Ž). Ovo pitanje, zajedno još uz tri pitanja/čestica, određuje ograničenja osoba zbog fizičkih poteškoća.

Ograničenja u dnevnim aktivnostima radi emocionalnih poteškoća navodi $24 \%$ ispitanika (11M/13Ž), dok je jednako posla obavilo $76 \%$ ispitanika $(32 \mathrm{M} / 44 \check{Z})$.

Kod $17 \%$ ispitanika zdravlje je u manjoj mjeri utjecalo na društvenu aktivnost, $11 \%$ ispitanika je odgovorilo da je umjereno utjecalo i $11 \%$ ispitanika da je prilično utjecalo.

Psihičko zdravlje izračunava se kroz pet čestica/pitanja. Za prikaz odgovora na česticu/pitanje: "Da li ste se osjećali tako potištenim da Vas ništa nije moglo razvedriti u protekla četiri tjedana?" odgovor "stalno" dala je jedna osoba (M), kao i odgovor "Skoro uvijek" (Ž). "Dobar dio vremena" odgovorilo je $4 \%$ ispitanika $(1 \mathrm{M} / 3 Z \check{Z})$, dok je $16 \%$ ispitanika $(6 \mathrm{M} / 10 Z \check{Z})$ odgovorilo da su se povremeno osjećali potištenim. Rijetko se osjećalo potištenim $31 \%$ ispitanika i nikad se nije osjećalo potištenim $47 \%$ ispitanika grada Cresa (23M/24乙̌).

Vitalnost i energija ispituju se kroz četiri čestice u SF-36 upitniku. $\mathrm{Na}$ pitanje "Da li ste puni energije i da li ste bili puni energije u protekla četiri tjedna?" 8\% ispitanika odgovorilo je da su bili stalno puni energije tijekom četiri tjedna (3M/5Ž), 23\% je bilo skoro uvijek dobre energije (11M/12Ž), dobar dio vremena je reklo $22 \%$ (12M/10Ž), 23\% ispitanika je bilo povremeno dobre energije (7M/16Ž). Od 15\% ispitanika koji su rijetko bili puni energije 4 su muškarca, a 11 žena, dok je $8 \%$ ispitanika izjavilo da nikad nije dobre volje $(3 \mathrm{M} / 5 \check{Z})$.

Tjelesne bolove $u$ protekla četiri tjedna nije imalo $23 \%$ ispitanika $(13 \mathrm{M} / 10 \mathrm{Z})$, dok je tešku i vrlo tešku bol izjavilo $10 \%$ ispitanika.

Opće zdravlje. Na pitanje: "Općenito: biste li rekli da je Vaše zdravlje...?", $5 \%$ ispitanika odgovorilo je da je njegovo zdravlje odlično $(3 \mathrm{M} / 2 \check{Z})$. $12 \%$ ispitanika izjavilo je da imaju vrlo dobro zdravlje (5M/7Ž), 38\% ispitanika imaju dobro zdravlje (16M/22Ž). 30\% ispitanika ima zadovoljavajuće zdravlje (13M/17Ž), 15\% osoba odgovorilo je da ima loše zdravlje (6M/9Ž).

Promjena zdravlja. $48 \%$ ispitanika izjasnilo se da je njihovo trenutačno zdravlje otprilike isto kao prije godinu dana (20M/28Ž). Puno bolje zdravlje u usporedbi s prošlom godinom imalo je 3\% muškaraca, a puno lošije zdravlje nego prije godinu dana imalo je $12 \%$ ispitanika (5M/7Ž).

Dobiveni rezultati ukazuju na to da postoje razlike po spolu. Muškarci u svim sastavnicama imaju veće vrijednosti od žena, iako društveno 
funkcioniranje i ograničenja u dnevnim aktivnostima radi emocionalnih poteškoća imaju najmanje razlika (Slika 1.).

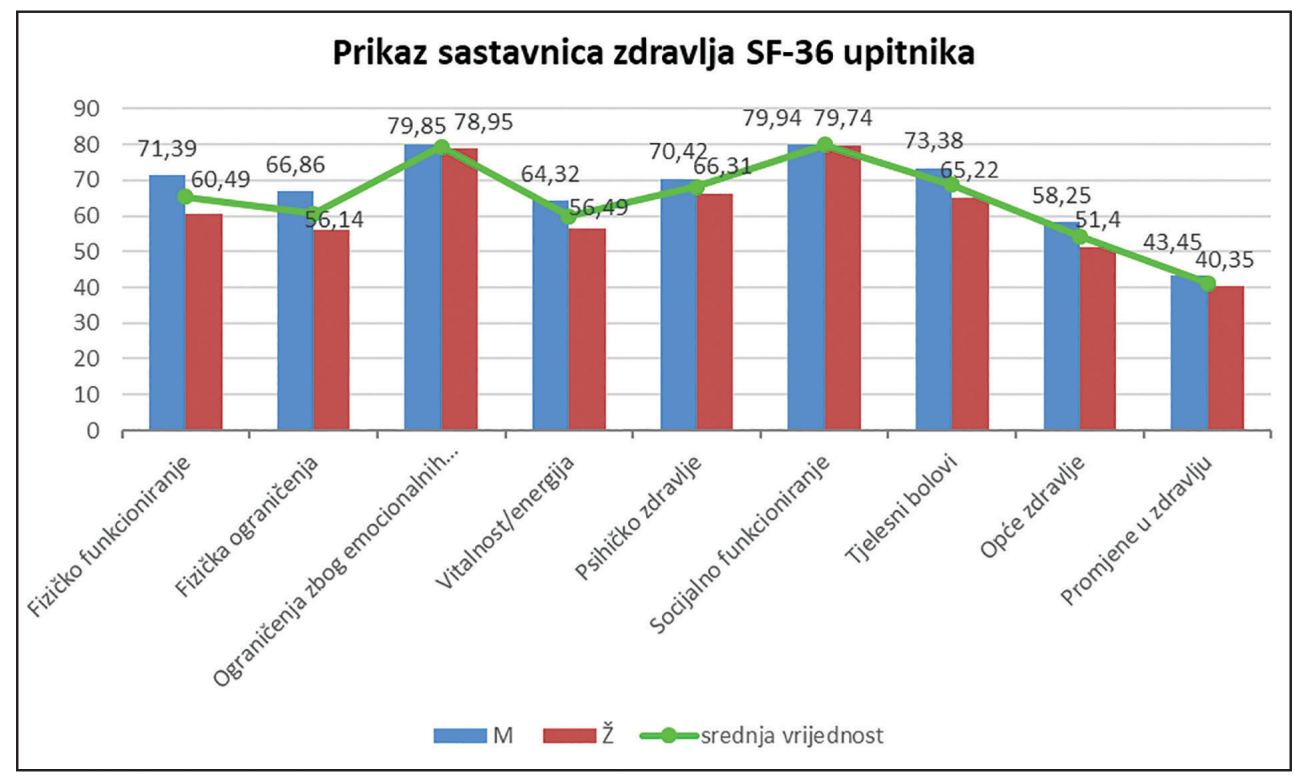

Slika 1. Procjena zdravlja stanovnika u odnosu na spol

Prilikom bodovanja pojedinih čestica unutar SF-36 upitnika, najveću vrijednost ima društveno funkcioniranje $(79,83)$, što je bolje od hrvatske populacije $(72,96)$, ali su im ograničenja radi emocionalnih poteškoća veća $(79,33$ vs. 72,42). Od ukupno 100 bodova, srednja vrijednost fizičkog funkcioniranja starije populacije grada Cresa iznosi 65,4, što je lošije u odnosu na opću populaciju RH $(69,94)$, a srednja vrijednost ograničenja zbog fizičkih poteškoća iznosi 60,75 , što je također lošije od populacije RH $(63,01)$. Srednja vrijednost psihičkog zdravlja starije populacije iznosi 68,08 što je više od populacije hrvatske $(61,71)$, kao i srednja vrijednost vitalnosti i energije (59,86 vs. 51,85). Sastavnice zdravlja o tjelesnoj boli iznose 68,73 vs. 64,51. Samoprocjena općeg zdravlja je nešto viša nego kod normi hrvatske populacije (54,35 vs. $53,40)$, a promjene u zdravlju su se manje događale kod starije populacije grada Cresa nego kod ukupnog stanovništva RH (41,25 vs. 44,79) (Slika 2.). 


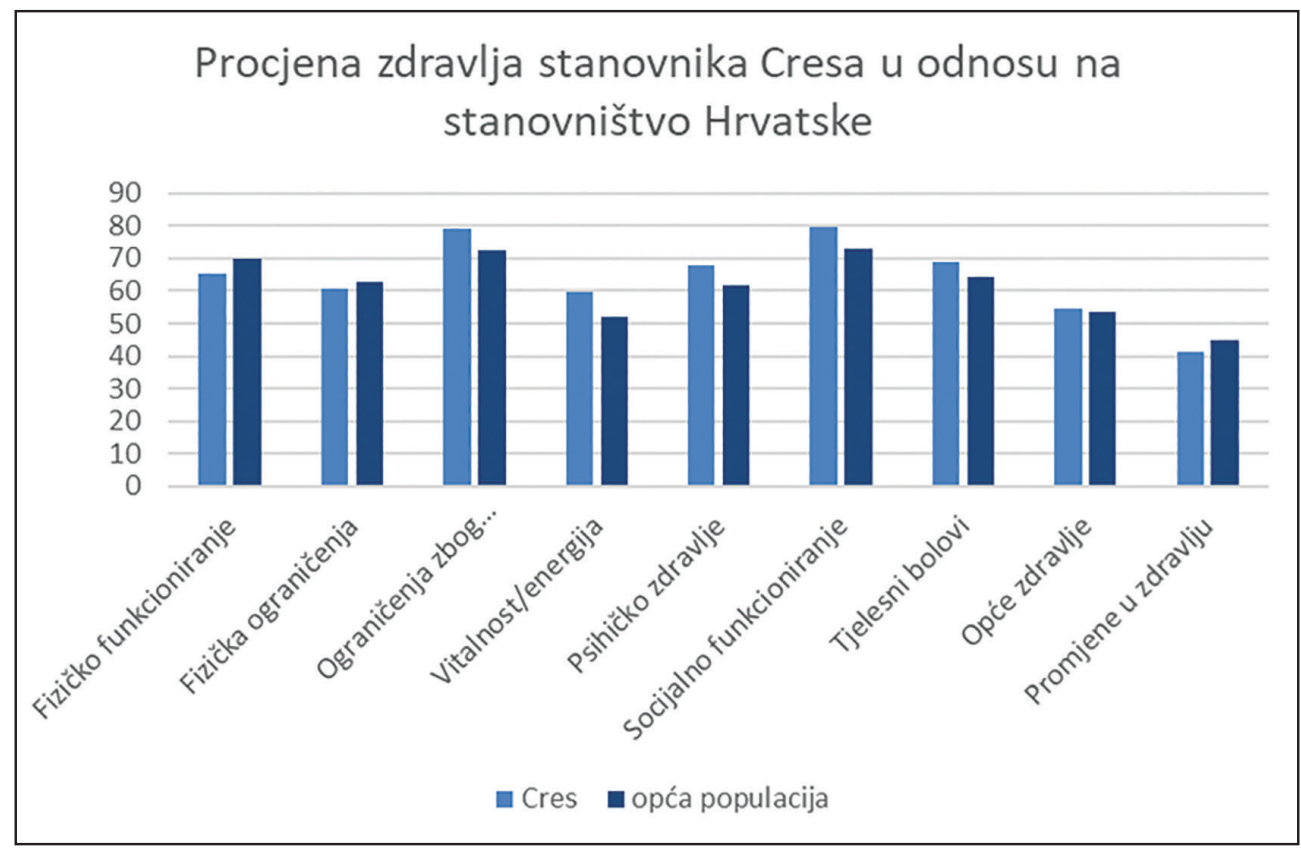

Slika 2. Procjena zdravlja starijih stanovnika otoka Cresa u odnosu na populaciju Republike Hrvatske

\section{Rasprava}

Procjena zdravstvenog statusa u populaciji važna je radi definiranja zdravstvenih potreba stanovnika, a time i organizacije zdravstvenih i socijalnih intervencija. Ograničenja u fizičkom funkcioniranju javljaju se tijekom starenja i važna su radi povezanosti uz smanjenu kvalitetu života, povećani rizik od invaliditeta, padova i prijeloma, depresiju, a u konačnici i uz povećane troškove zdravstvene zaštite. Redovita fizička aktivnost jedan je od najvažnijih faktora u smanjenju funkcionalnog ograničenja. Prema istraživanju, žene u odnosu na muškarce subjektivno lošije ocjenjuju svoju fizičku funkcionalnost, kao i ograničenost u zdravlju zbog fizičkih poteškoća (6), no u konačnici imaju bolju fizičku funkcionalnost (7). Ipak, ponderirani rezultati istraživanja ukazuju na bolje fizičko funkcioniranje muškaraca nego žena, što je moguće zbog toga što nisu bili objektivni u istraživanju ili zbog toga što su mlađi ispitanici u ovom istraživanju, te iskazuju bolje rezultate. Više od polovice starijih ispitanika grada Cresa procijenila je da nisu imali nikakva ograničenja u obavljanju nekih dnevnih aktivnosti ili poslova zbog emocionalnih poteškoća, iako podosta istraživanja govori o tome da postoji velika 
uzročno-posljedična povezanost ograničenja u radu zbog emocionalnih poteškoća (8). Zbog stalnog osjećaja umora, smanjenog interesa za komunikaciju, poremećaja u sjećanju i koncentraciji, uz moguće simptome depresije, dobivene rezultate možemo povezati sa "zatvorenijom" subjektivnosti ispitanika na području emocionalnih poteškoća i psihičkog ili mentalnog zdravlja. Rezultati ovog istraživanja su također pokazali da su ograničenja zbog emocionalnih poteškoća u svakodnevnim životnim aktivnostima manja kod muškaraca nego kod žena, zbog mogućnosti različite percepcije u emocionalnom odgovoru žena i muškaraca. Neke studije o samoprocjeni emocionalnog odgovora pokazuju da su žene emocionalno osjetljivije od muškaraca (9).

Društveno funkcioniranje i zdravlje snažno su povezani i dokazani u nizu istraživanja, te društvena povezanost svake osobe ima vrlo važnu ulogu u zdravom starenju (10). Prema istraživanju Michaela Marmota, društvena aktivnost osoba djeluje kao zaštitni čimbenik razvoja bolesti i poboljšava kvalitetu života (11). Važno je napomenuti da će osobe koje su cijeli život društveno aktivne tako nastaviti i u starosti (12). Moguće je, upravo zbog toga, da rezultat istraživanja pokazuje vrlo visoku bodovnu vrijednost društvenog funkcioniranja u ovom istraživanju, iako je na drugim hrvatskim otocima prikazano slabije društveno funkcioniranje zbog moguće izoliranosti i male populacije (13). S druge strane, rezultati provedene studije kvalitete života na otocima ukazuju na to da je kvaliteta života na otocima podosta visoka, što je popraćeno i dobrim psihičkim zdravljem stanovnika (14). Unatoč lošijoj dostupnosti zdravstvene zaštite, lijekovima te slabijoj skrbi za starije osobe nego na kopnu, subjektivni zdravstveni status starije populacije vrlo je visok. U istraživanju je prikazano da su osjećaj povezanosti i međusobna bliskost članova zajednice i obitelji na otoku vrlo snažno prisutni, pa većina starijih osoba osjeća pripadnost i prihvaćenost (14). Starijoj populaciji grada Cresa psihičko zdravlje je vrednovano vrlo visoko, iako muškarci iskazuju bolje psihičko zdravlje nego žene, no za vrlo malu razliku bodovne vrijednosti. Jedno istraživanje govori da su spolne razlike zadovoljstva životom vrlo male (15), a pripisuju se raznim fizičkim, psihičkim i društvenim obilježjima. Istraživanjem je utvrđeno da optimalno zdravstveno stanje, fizičko i psihičko zdravlje te društveno funkcioniranje utječu na vitalnost i energiju starije osobe (16). Starija populacija grada Cresa skoro je uvijek, povremeno ili dobar dio vremena puna energije.

Buduće da starija populacija predstavlja veliku skupinu stanovništva u svijetu, pa i u RH, posebna pozornost treba se posvetiti tjelesnoj boli. Neke od posljedica tjelesne boli jesu smanjena pokretljivost, smanjena socijalizacija, 
poremećaji spavanja, spora rehabilitacija. Važno je znati da psihičko ili mentalno zdravlje može biti povezano uz tjelesnu bol (17). Danas se općenito smatra da bol utječe na muškarce i žene različito. Starija populacija grada Cresa u razgovoru s istraživačem podosta se žalila na tjelesnu bol, te su žene u istraživanju imale veće tjelesne bolove u protekla četiri tjedna, što možemo pripisati činjenici da žene brže traže pomoć za bol i češće pričaju o tjelesnoj boli (17).

Najmanja srednja vrijednost starije populacije grada Cresa iz cijelog upitnika SF-36 upravo je bila kod percepcije vlastitog općeg zdravlja te je iznosila 54,35, što potvrđuje da mnogi stariji ljudi doživljavaju starenje negativno, opisujući svoje stanje kao loše ili opadajuće (18).

Promjene u zdravlju u usporedbi s prošlom godinom više su se događale kod starijih muškaraca grada Cresa, no sveukupan je rezultat pokazao da se nije toliko promijenilo zdravlje kod cijelog uzorka u istraživanju.

Istraživanja iz 2000. godine ukazuju na to da su rezultati zdravstvenog stanja ukupne populacije prema SF-36 upitniku u Hrvatskoj vrlo slični rezultatima zdravstvenog stanja ukupne populacije u drugim europskim zemljama (19). Uspoređivanjem zdravstvenog stanja hrvatske populacije i starije populacije grada Cresa uočila su se neka odstupanja. Fizičko ili tjelesno funkcioniranje starije populacije grada Cresa lošije je u odnosu na hrvatsku populaciju $(65,4$ vs. 69,94$)$, što možemo pripisati godinama starosti, iako je procijenjena ograničenost zbog fizičkih poteškoća manje prisutna u gradu Cresu nego u ukupnoj hrvatskoj populaciji. Objašnjenje ovog opažanja mogu biti manja očekivanja populacije koja živi na otocima. Naime, dnevne su aktivnosti najčešće sukladne uobičajenom načinu života koji se sastoji od rutina koje se ipak lakše ispunjavaju na otocima. Isto je objašnjenje i manje otočke ograničenosti u svakodnevnim životnim aktivnostima zbog emocionalnih poteškoća. Međutim, postoji i mogućnost neiskazivanja stvarnog emotivnog stanja, što može biti posljedica života u zatvorenoj sredini. Vitalnost i energija u većoj su vrijednosti nego u hrvatskoj populaciji, što ukazuje na to da su starije osobe koje žive na otoku potencijalno snažnije, produktivnije i kreativnije nego što se misli te iskazuju i jače psihičko ili mentalno zdravlje. Društveno funkcioniranje također je više izraženo, što se pripisuje motiviranosti starijih osoba za sudjelovanje u aktivnostima koje se nude unutar otoka. Život na otoku ima svoje dobre specifičnosti u smislu potrebe oslanjanja na vlastite snage te aktivnosti koje omogućavaju produktivno starenje. Samim time je i samoprocjena općeg zdravlja starijih stanovnika nešto veća nego kod normi opće hrvatske populacije. Može se primijetiti da u svim sastavnicama 
zdravlja stariji muškarci imaju bolje vrijednosti nego žene, što je slično populaciji RH, gdje muškarci također imaju višu bodovnu vrijednost svake od odrednica zdravlja (19).

\section{Zaključak}

Dobiveni rezultati dovode do zaključka da je subjektivna procjena zdravlja starijeg stanovništva u gradu Cresu bolja nego u hrvatskoj populaciji. U većini zdravstvenih parametara, rezultati su prikazali bolje zdravstveno stanje, osim kod fizičkog funkcioniranja, gdje je dobivena manja srednja vrijednost u odnosu na opću populaciju RH. Muškarci imaju bolju kvalitetu života nego žene te svoje zdravlje percipiraju boljim nego žene. Muškarci češće bolje fizički funkcioniraju, dok žene osjećaju veći postotak tjelesne boli. Procjene zdravlja pružaju korisne uvide u kratkoročne i dugoročne promjene u zdravlju populacije, uz određena ograničenja koja ponekad onemogućavaju donošenje čvrstih zaključaka iz njihovih analiza. Ipak percepcija osobe o svom vlastitom zdravlju važna je i u konačnici daje značajne informacije o zdravlju cijele populacije.

Doprinosi autora: LB: Koncept i dizajn istraživanja, interpretacija podataka, pisanje članka; MK: Prikupljanje podataka, analiza, izrada članka; ZT: Tumačenje podataka, kritički i intelektualni doprinos obradi podataka, pisanje članka.

Sukobi interesa: Autori izjavljuju da nemaju sukob interesa

\section{Reference}

1. Statistical Office of the European Communities. Population structure and ageing Statistics Explained [Internet]. 2016. Available from: http://ec.europa.eu/eurostat/ statistics-explained/index.php/Population_structure_and_ageing

2. Državni zavod za statistiku. Popis stanovništva, kućanstava i stanova 2011. Zagreb, 2013.

3. World Health Organization (WHO). Active ageing: a policy framework.

4. Duraković Z. Gerijatrija - Medicina starije dobi. Drugo izdanje. Duraković Z, editor. Zagreb: C.T. Poslovne informacije d.o.o., 2007.

5. Ware J, Snow K, Kosinski M, Gandek B. SF-36 Health survey Manual and Interpretation Guide. 1993.

6. Aoyama M, Suzuki Y, Onishi J, Kuzuya M. Physical and functional factors in activities of daily living that predict falls in community-dwelling older women. Geriatr Gerontol Int [Internet];2011:11. Dostupno na: https://doi.org/10.1111/j.1447-0594.2010.00685.x

7. A Paw MJMC, Dekker JM, Feskens EJM, Schouten EG, Kromhout D. How to select a frail elderly population? A comparison of three working definitions. J Clin Epidemiol. 1999;52(11):1015-21.

8. Wieser TW, Weinberger M. Psychosocial issues in elderly minority population. Geritr Psycho-Oncology. 2015;5(1):145-50. 
9. McRae K, Ochsner KN, Mauss IB, Gabrielli JJD, Gross J. Gender differences in Emotion Regulation: an fMRI study of cognitive reappraisal. Gr Process Intergr Relat. 2008;11(2):143-62.

10. Cohen S. Social Relationships and Health. Vol. 59, American Psychological Association, 2004. p. 676-84.

11. Marmot M. Closing the health gap. Scand J Public Health. 2017;45(7):723-31.

12. Marmot M, Goldblatt P, Allen J. Fair Society Healthy Lives (The Marmot review). 2010.

13. Vuletić Mavrinac G, Mujkić A. Mental health and health related quality of life in Croatian island population. Croat Med J. 2006;47(4):635-40.

14. Podgorelec S, Klempić Bogadi S. Kvaliteta života starijeg stanovništva na hrvatskim otocima. Gerontologija. 2015;41(2):108-26.

15. Hill AM, Etherton-Beer C, Haines TP. Tailored Education for Older Patients to Facilitate Engagement in Falls Prevention Strategies after Hospital Discharge - A Pilot Randomized Controlled Trial. Baradaran HR, editor. PLoS One. 2013 May;8(5):e63450.

16. Soderbacka T, Nystrom L, Fagerstrom L. Older person's experiences of what influences their vitality - a study of 65-and 75-years olds in Finland and Sweden. Scand J Caring Sci. 2017;31(2):378-87.

17. Schofield P. Pain in older Adults: Epidemiology, Impact and Barrier to Management. Rev Pain. 2007;1(1):12-24.

18. Warmoth K, Tarrant M, Abraham C, Lang I. Older Adults' perceptions of ageing and their health and functioning: a systematic review of observational studies. Psychol Heal Med. 2016;21(5):531-50.

19. Jureša V, Ivanković D, Vuletić G, Babić-Banaszak A, Srček I, Mastilica M, et al. The Croatian Health Survey - SF-36: I. General Quality of Life Assessment. Coll antropol. 2000;24(1):69-78. 


\title{
ASSESSMENT OF HEALTH STATE OF THE ELDERLY POPULATION OF THE ISLAND OF CRES
}

\begin{abstract}
Introduction. Population aging poses a challenge in economic, business, health and social terms. The health assessment of the needs of the elderly population is carried out at the level of larger communities. However, the population on the islands is predominantly old and is constantly aging. $19.9 \%$ of the population on Cres are elderly, and the aim of this research work is to assess the health status of the elderly population of the town of Cres. Materials and methods. The Short form health survey-36 (SF-36) was used to assess health status. Measures of health state include components such as physical, mental and social functioning, vitality and energy, various limitations due to physical or mental difficulties, physical pain, as well as perception of an individual's general health. The respondents are elderly people living on the island of Cres. Results. The study involved 100 residents of the town of Cres (43 men and 57 women), aged 65 and over. The obtained results according to the scoring of each individual component indicate that social functioning is best rated (79.83), followed by health restrictions due to emotional difficulties (79.33), psychological or mental health (68.08), physical functioning (65.4), health restriction due to physical difficulties (60.75), vitality and energy (59.86) and general health (54.35). Conclusion. The assessment of the health status of the elderly population of the island of Cres is better when compared to the general Croatian population, and thus the quality of life is better. Men have a better quality of life than women, and they perceive their health better than women. The importance of assessing the health of the population is manifested in obtaining short-term and long-term data on changes in the health of the population, which enable creating interventions aimed at improving the health of older people living in smaller communities.
\end{abstract}

Keywords: elderly, health assessment, SF-36. 